Génét. Sél. Evol., 1983, 15 (2), 185-200

\title{
Genetic properties of North African Drosophila melanogaster and comparison with European and Afrotropical populations
}

\author{
P. CAPY, J.R. DAVID, R. ALLEMAND (*), P. HYYTIA and J. ROUAULT \\ C.N.R.S., Laboratoire de Biologie et Génétique évolutives, F 91190 Gif-sur-Yvette, \\ (*) Laboratoire de Biologie des Populations, \\ Université Claude Bernard, F 69622 Villeurbanne
}

\begin{abstract}
Summary
Four kinds of genetic traits (i.e. allozyme frequencies, six biometrical characters, ethanol tolerance and oviposition rhythm) which all exhibit latitudinal clines, were measured in a Tunisian population. Allozymes and morphology were also studied in an Egyptian population. The data were compared with those obtained for European and Afrotropical flies and also with a Seychellian population recently introduced in this archipelago. In all cases, the morphology was studied on the second laboratory generation of isofemale lines.

North African flies were found to be very close to European flies for allozyme frequencies and ethanol tolerance, but very close to Afrotropical flies for ovariole number, wing and thorax lengths. For other traits such as adult weight, number of sternopleural chaetae and oviposition rhythm, the North African flies were intermediate to those from Europe and Tropical Africa while for the number of abdominal chaetae, the North African flies were superior to both of the other populations. Such observations demonstrate that significant local genetic divergences may be superimposed to the general tendency of the latitudinal cline.

In spite of their tropical habitat, the Seychellian flies were found to be very similar to those living in a temperate country and, for all morphological traits, a striking similarity was observed with the North African populations. It is, however, not yet possible to suggest a definitive answer for the origin of this introduced population.
\end{abstract}

Key words : Drosophila melanogaster, ecological genetics, geographic races, latitudinal clines.

\begin{abstract}
Résumé
Caractéristiques génétiques des Drosophila melanogaster d'Afrique du Nord et comparaison avec les populations d'Europe et d'Afrique tropicale
\end{abstract}

Quatre types de caractères (fréquences enzymatiques de 7 locus, 6 caractères biométriques, la tolérance à l'éthanol et le rythme d'oviposition) ont été mesurés sur une population tunisienne. Les fréquences enzymatiques et les caractères morphologiques ont été également étudiés dans une population égyptienne. Les résultats ont été comparés aux caractéristiques de mouches d'Europe, d'Afrique équatoriale et également à celles d'une population des Seychelles récemment introduite dans cet archipel. Dans tous les cas, l'étude biométrique a été réalisée sur la première génération de laboratoire de lignées isofemelles. 
Les mouches nord africaines apparaissent très proches des mouches Européennes pour les fréquences enzymatiques et la tolérance à l'éthanol, par contre elles sont aussi très proches des mouches d'Afrique équatoriale pour le nombre d'ovarioles, les longueurs d'aile et le thorax. Pour les autres caractères tels que le poids des adultes, le nombre des soies sternopleurales et le rythme d'oviposition, elles sont en position intermédiaire. Finalement, elles présentent des valeurs supérieures à celles observées en Europe et en Afrique tropicale pour le nombre de soies abdominales. De telles observations démontrent que des divergences génétiques locales peuvent s'ajouter à la tendance générale des clines latitudinaux.

Malgré leur habitat tropical, les mouches des Seychelles sont très proches de celles vivant en pays tempérés et pour tous les caractères morphologiques une grande analogie est observée avec les populations du nord de l'Afrique. Il n'est, cependant, pas encore possible de préciser définitivement l'origine de cette population.

Mots clés : Drosophila melanogaster, génétique écologique, races géographiques, clines latitudinaux.

\section{Introduction}

One of the most persuasive pieces of evidence that natural selection is acting on the genetic structure of wild populations is the occurrence of latitudinal clines which are known in a great number of species (MAYR, 1963 ; DOBZHANSKY, 1970). However, as pointed out by ENDLER (1977), the observation of such clines cannot be considered, by itself, as a demonstration of selective effects : the occurrence of stochastic processes is always difficult to exclude.

The cosmopolitan Drosophila melanogaster, which is one of the only two Drosophila species able to proliferate both under tropical and temperate climates (DAVID and TSACAS, 1981), is an excellent model for the analysis of such regular geographic variations. For the moment, latitudinal clines have been described for various morphological traits (TANTAWY and MALlaH, 1961; DAvid and BocQUeT, 1975a), physiological traits (DAVID and BOCQUET, 1975b ; ALLEMAND and DAVID, 1976), chromosomal inversions (METTLER et $a l ., 1977$ ) and allozyme frequencies (VOELKER et al., 1978 ; OAKESHOTT et al., 1981a, b ; DAVID, 1982 ; SINGH et al., 1982).

The best documented information presently available is provided by the analysis of allozyme polymorphism since convergent observations have been obtained on different continents (North America, Europe, equatorial Africa, East Asia and Australia) which harbour populations with very different histories (DAVID and TSACAS, 1981). As argued for example by DAVID and BOCQUET (1975a) and OAKESHOTT et al. (1981a, b) the occurrence of parallel clines on different continents is a strong argument in favour of a selective pressure. However, latitude (and related environmental climatic variables) never explain the total genetic variability between populations. Longitudinal influences, for example, may be observed even when a single continent is considered (OAKESHOTT et al., 1981a, b ; LOUIS et al., 1982).

Biochemical polymorphism is a remarkable means of analysing the genetic differentiation between allopatric populations of the same species. Within species of Drosophila, allozyme frequencies are generally stable (AyAlA et al., 1974 ; PowELl, 1975 ; Nevo, 1978). This, however, may be interpreted either as a consequence of balancing selection or, under the neutralist theory, by the occurence of some genetic exchange between populations (KimURA and MARUYAMA, 1971 ; Lewontin, 1974 ; KimURA, 1979). For a better understanding of the significance of allopatric variations in $D$. melanogaster, it now appears necessary to extend the analysis to populations not yet studied and also to increase the number of genetically variable traits which are measured on the same population. 
We present here a study of north African flies analysed for four kinds of characters which all exhibit latitudinal clines : allozyme frequencies, morphology, alcohol tolerance and oviposition rhythm. These populations are interesting because of their intermediate position between tropical Africa (which harbour the ancestral populations of the species) and Europe. It also appeared worthwhile to include in this comparison a population recently introduced to the Seychelles (DAVID and CAPY, 1982).

\section{Material and methods}

The major aim of this study was to compare north African populations with those living under temperate or tropical climates. For added interest we have also included in the comparison information on a population recently introduced to the Seychelles (DAVID and CAPY, 1982). The populations have been compared for a total of 15 different genetic traits, namely 7 allozyme loci, 6 different morphological characters, plus tolerance to ethanol and oviposition rhythm, which we will refer to as biometrical traits.

\section{A. Populations and sampling procedures}

Two north African populations were studied, one from Alexandria (Egypt) and one from Nasr'allah (Tunisia). Wild collected females were brought to the laboratory and isolated in single vials to initiate isofemale lines. These lines were used to study allozyme variants and the biometrical traits. In the case of the Tunisian population, two outbreeding strains were also made by mixing 15 different lines. An alternative sampling procedure was used to examine morphological traits in the north African population. As wild living females are often inseminated by more than one male (MILKMAN and ZEITLER, 1974) their offspring are a mixture of full and half-sibs. To avoid this imprecision, new lines were founded from the first laboratory generation by crossing a virgin female of a line with a male of another line. Two of the initial lines were used to initiate only one new line so that, in all cases, the studied flies corresponded to the second generation grown in the laboratory. This procedure produces full-sib individuals in each family, while avoiding the possible drawbacks of inbreeding, drift or laboratory selection. Information on the populations from Europe and tropical Africa has largely been taken from previously published studies from this laboratory. Data for the allozyme frequencies have been taken from previously published reports (DAvid, 1982 ; SINGH et al., 1982). Biometrical data too have been published for European and tropical African populations, populations founded with several females collected in many localities. However, these populations had been kept in the laboratory for several months or even years prior to study. We wished here to obtain more precise information on natural populations living in these countries by submitting some of them to the isofemale line analysis, immediately after the capture of wild living adults. Two French populations, Malaucène and Villeurbanne, were studied in that way and also two Afrotropical populations from Brazzaville (Congo) and Cotonou (Bénin). Ethanol tolerance and oviposition rhythm were measured on mixed strains from Congo and Villeurbanne after two or three generations in the laboratory.

For the Seychellian population, data are taken from a previous paper (DAVID and CAPY, 1982) to which some new results will be added on allozyme frequencies and oviposition rhythm. 


\section{B. Characters}

Enzymatic polymorphism was studied at 7 loci using starch gel electrophoresis. Those were $A d h, O d h, \alpha G p d h, E s t-6, E s t-C, G 6 p d$ and Pgm. For each line studied, two adult flies were taken at random.

Six different morphological traits were measured as described by DAVID (1979). The offspring of each couple were reared at $25^{\circ} \mathrm{C}$ on a killed yeast medium under low larval density and 10 individuals were measured in each line. Ovariole number was determined on females while the five other traits, i.e. fresh weight, thorax and wing lengths, sternopleural and abdominal chaetae numbers, were measured on males. The mean of each line was taken as a single observation.

Ethanol tolerance was determined by studying adult survival in the presente of different concentrations of alcohol (see DAVID et al., 1974). The daily rhythm of oviposition was measured as described by ALLEMAND (1974). Both characters were measured for the mixed strains of Tunisian flies, and on the mixed strains from the Congo and Villeurbanne described above.

\section{Results}

\section{A. Allozyme frequencies}

Allelic frequencies at 7 polymorphic loci are given in table 1 and compared with results from French, Afrotropical and Seychellian populations. For the $A d h$ locus, a high frequency $(0.95)$ of $\mathrm{F}$ allele is observed in Tunisia, as it is in France. The Egyptian population, on the other hand, is characterized by a lower frequency of this allele. For all the other loci, the two north African populations have similar frequencies and are generally close to the west European sample. The main differences are a higher frequency of $\alpha G p d h^{\mathrm{S}}$ and the absence of Est-Cs allele in North Africa.

The generalized genetic distances and normalized identities (NEI, 1972) are given in table 2. The Egyptian population, for which only 5 loci were studied, was not included in this calculation. The four groups here compared may be distributed in two classes : European, Tunisian and Seychellian populations are very close $(D<0.1)$ while Afrotropical populations are notably separate from the three others $(\mathrm{D}>0.3)$.

\section{B. Biometrical traits}

For three geographic origins (France, tropical Africa and North Africa), two populations were studied with the isofemale lines technique. The average values for the 6 measured traits are given in table 3 and comparisons between the two populations of each geographic group are done by a $t$ test. Among 18 comparisons, 8 are significant. The two Afrotropical populations are the most different while the two north African are the most similar. The best discriminative trait is wing length while the most stable within a geographic area is the number of abdominal chaetae.

Table 3 also allows a comparison of the three geographic groups. For the various traits, the greatest difference is generally observed between European and Afrotropical .... nnfirmino nrevious conclusions based on the analysis of many laboratory strains 
(DAvid et al., 1977). In all cases, values measured in European populations are much higher than in the tropics. North African populations often occupy an intermediate position (weight, wing and thorax lengths, sternopleural chaetae). They are however superior to European flies for the number of abdominal chaetae while they are almost identical to tropical flies for the ovariole number.

\section{TABLE 1}

Comparison of allelic frequencies at seven loci in north African, European, tropical African and Seychellian populations.

The European and Afrotropical data correspond to the average of 7 and 6 populations (see DAVID, 1982) for the first five loci and were extracted from SINGH et al. (1982) for the last two loci.

Comparaison des fréquences alléliques à 7 locus des populations Nord Africaines, Européennes, d'Afrique tropicale et des Seychelles.

Les données des populations d'Europe et d'Afrique tropicale sont les moyennes des valeurs de 7 et 6 populations (voir DAVID, 1982) pour les cinq premiers locus et sont tirées de SINGH et al. (1982) pour les deux derniers.

\begin{tabular}{|c|c|c|c|c|c|c|}
\hline \multicolumn{2}{|c|}{ Locus and alleles } & France & Tropical & Nasr'Allah & Alexandrie & Seychelles \\
\hline Adh & $\begin{array}{l}\mathrm{S} \\
\mathrm{F} \\
\mathrm{n}\end{array}$ & $\begin{array}{r}.060 \\
.940 \\
1752\end{array}$ & $\begin{array}{r}.968 \\
.032 \\
2518\end{array}$ & $\begin{array}{l}.047 \\
.953 \\
212\end{array}$ & $\begin{array}{r}.237 \\
.763 \\
116\end{array}$ & $\begin{array}{l}.151 \\
.849 \\
104\end{array}$ \\
\hline Odh & $\begin{array}{l}\mathrm{S} \\
\mathrm{F} \\
\mathrm{n}\end{array}$ & $\begin{array}{r}.029 \\
.971 \\
1376\end{array}$ & $\begin{array}{r}.107 \\
.893 \\
1766\end{array}$ & $\begin{array}{l}.005 \\
.995 \\
212\end{array}$ & $\begin{array}{l}.043 \\
.957 \\
116\end{array}$ & $\begin{array}{r}-\overline{1.000} \\
104\end{array}$ \\
\hline$\alpha \mathrm{Gpdh}$ & $\begin{array}{l}\mathrm{S} \\
\mathrm{F} \\
\mathrm{n}\end{array}$ & $\begin{array}{r}.408 \\
.592 \\
1476\end{array}$ & $\begin{array}{r}.013 \\
.987 \\
2238\end{array}$ & $\begin{array}{l}.552 \\
.448 \\
212\end{array}$ & $\begin{array}{r}.569 \\
.432 \\
116\end{array}$ & $\begin{array}{l}.491 \\
.509 \\
104\end{array}$ \\
\hline Est-6 & $\begin{array}{l}\mathrm{S}_{1}-\mathrm{S}_{2} \\
\mathrm{~S} \\
\mathrm{~F} \\
\mathrm{~F}_{1}-\mathrm{F}_{2} \\
\mathrm{n}\end{array}$ & $\begin{array}{r}.025 \\
.697 \\
.272 \\
.005 \\
1416\end{array}$ & $\begin{array}{r}.018 \\
.310 \\
.623 \\
.049 \\
1836\end{array}$ & $\begin{array}{l}.019 \\
.731 \\
.250 \\
- \\
212\end{array}$ & $\begin{array}{c}.032 \\
.798 \\
.170 \\
- \\
116\end{array}$ & $\begin{array}{l}.047 \\
.689 \\
.264 \\
- \\
104\end{array}$ \\
\hline Est-C & $\begin{array}{l}\mathrm{S} \\
\mathrm{F} \\
\mathrm{V} \\
\mathrm{n}\end{array}$ & $\begin{array}{r}.083 \\
.881 \\
.036 \\
1438\end{array}$ & $\begin{array}{r}.163 \\
.505 \\
.332 \\
1736\end{array}$ & $\begin{array}{l}- \\
.995 \\
.005 \\
212\end{array}$ & $\begin{array}{l}-\overline{948} \\
.052 \\
116\end{array}$ & $\begin{array}{l}- \\
.929 \\
.071 \\
104\end{array}$ \\
\hline G6pd & $\begin{array}{l}\mathrm{S} \\
\mathrm{F} \\
\mathrm{n}\end{array}$ & $\begin{array}{c}.160 \\
.840 \\
40\end{array}$ & $\begin{array}{r}.416 \\
.584 \\
56\end{array}$ & $\begin{array}{l}.189 \\
.811 \\
212\end{array}$ & & $\begin{array}{r}.167 \\
.833 \\
104\end{array}$ \\
\hline Pgm & $\begin{array}{l}\mathrm{S} \\
\mathrm{F} \\
\mathrm{V} \\
\mathrm{n}\end{array}$ & $\begin{array}{l}.020 \\
.980 \\
- \\
40\end{array}$ & $\begin{array}{l}.062 \\
.709 \\
.229\end{array}$ & $\begin{array}{l}.028 \\
.944 \\
.028 \\
212\end{array}$ & & $\begin{array}{c}- \\
1.000 \\
- \\
104\end{array}$ \\
\hline
\end{tabular}




\section{TABLE 2}

Genetic distances (above diagonal) and normalized identities (under diagonal) according to NEI (1972) calculated for 7 polymorphic loci

(the Egyptian population is not included in this comparison).

Distances génétiques (au-dessus de la diagonale)

et identités normalisées (au-dessous de la diagonale)

d'après NEI (1972), calculées pour 7 locus polymorphiques

(la population égyptienne n'est pas inclue dans cette comparaison).

\begin{tabular}{|c|c|c|c|c|c|}
\hline \multicolumn{6}{|c|}{ GENETIC DISTANCES } \\
\hline \multirow{5}{*}{ 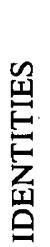 } & & Europe & T. Africa & N. Africa & Seychelles \\
\hline & Europe & - & 0.316 & 0.008 & 0.089 \\
\hline & T. Africa & 0.729 & - & 0.379 & 0.326 \\
\hline & N. Africa . & 0.992 & 0.684 & - & 0.085 \\
\hline & Seychelles. & 0.914 & 0.722 & 0.918 & - \\
\hline
\end{tabular}

It appeared therefore necessary to combine the different traits in a more general comparison and the results of two different techniques are presented here.

The first method is to consider the " biometrical profiles " (LEFEBVRE, 1978 ; CAPY, 1982) of the seven populations. The means and variances of the various traits are very different so that an homogenization of scale is necessary. In each case a transformation was done so that the general mean becomes 0 and the variance 1 (standardized variable). After that, the position of the mean of each population is shown graphically and the values for different traits in the same population are joined by a line so that a profile is visualized (fig.1).

We see that the two French populations are very similar and always above the zero line while the two Afrotropical populations, although more distant, are always below the zero line. The two north African populations are very close : they are above the zero for the first three traits and below for the last three. The Seychellian population exhibit a profile similar to those of north African flies.

For a more accurate comparison of two profiles, two properties must be considered : first the overall distance ; second the parallelism of the lines. To estimate the distance, we used a very simple, empirical formula, as follows :

$$
\mathrm{d}=\sum_{\mathrm{l}}^{\mathrm{n}}\left|\mathrm{X}_{\mathrm{i}}-\mathrm{Y}_{\mathrm{i}}\right|
$$

where $X_{i}$ and $Y_{i}$ are the mean values of trait $i$ in populations $X$ and $Y$, and $n$ is the number of traits. The parallelism of two profiles was estimated by the coefficient of correlation $r$. The values of these two parameters for the 21 possible comparisons are given in table 4 . 


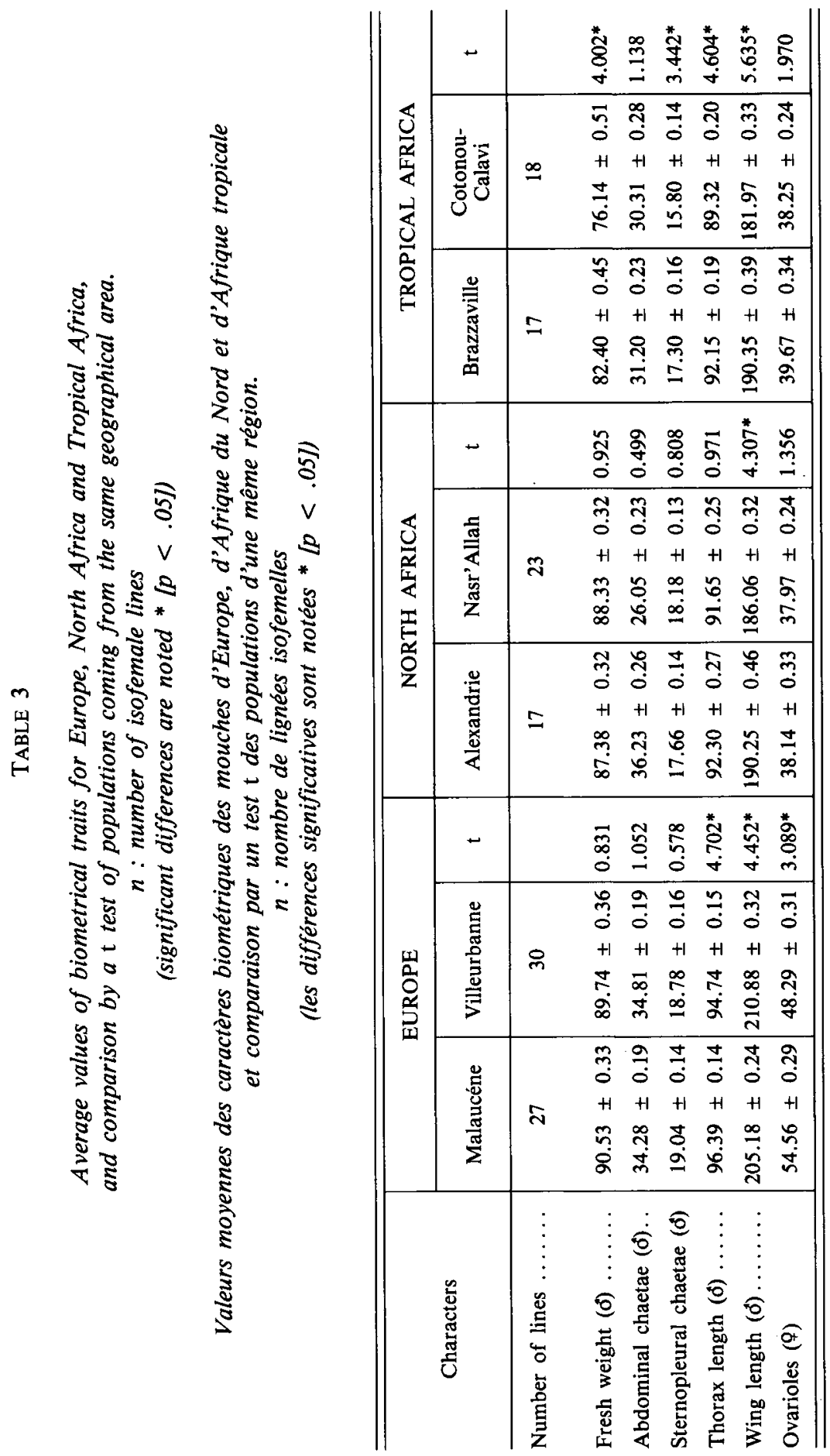




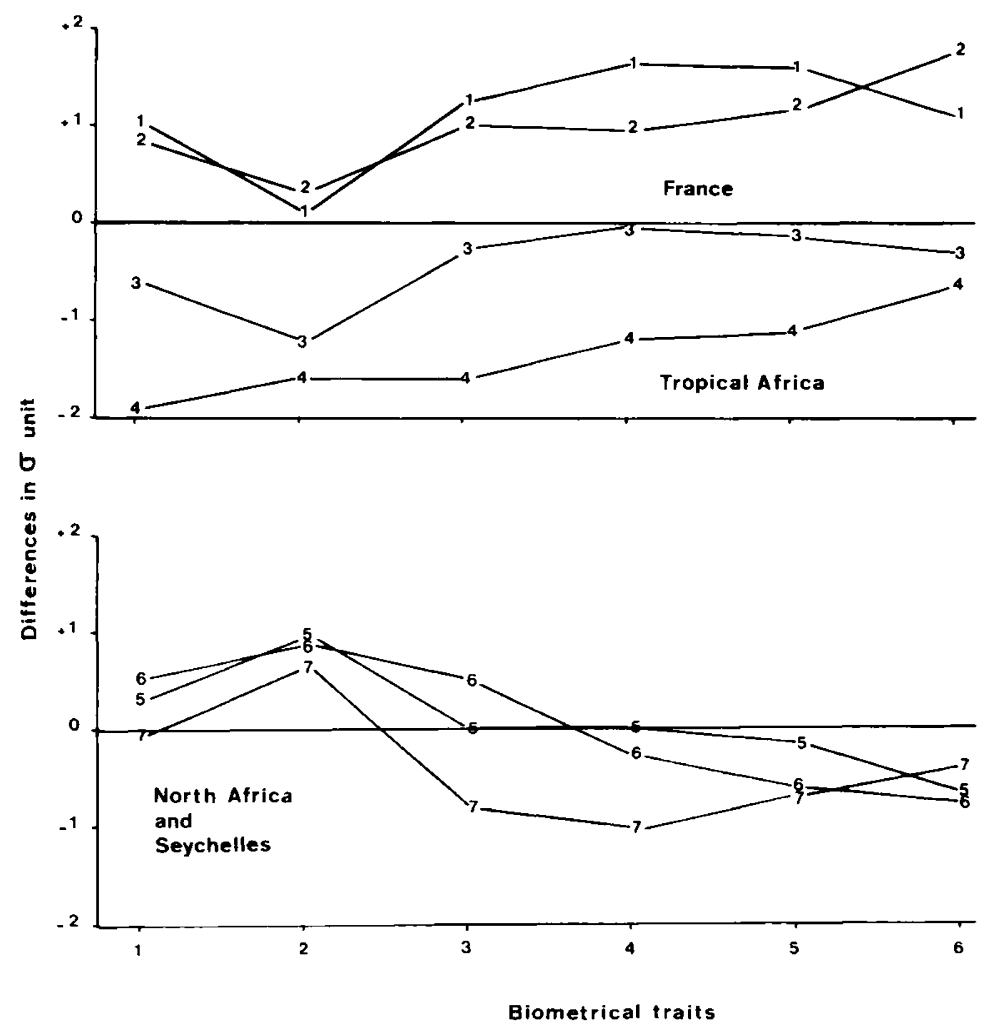

FIG. 1

Biometrical profiles of the seven populations (see text for details).

Populations : 1. Malaucène, 2. Villeurbanne, 3. Cotonou, 4. Brazzaville, 5. Alexandria, 6. Nasr'Allah, 7. Seychelles.

Traits : 1. Weight, 2. Number of abdominal chaetae, 3. Number of sternopleural chaetae, 4. Thorax length, 5. Wing length, 6. Ovariole number.

Profils biométriques des 7 populations étudiées (voir le texte pour plus de détails).

Populations: 1. Malaucène, 2. Villeurbanne, 3. Cotonou, 4. Brazzaville, 5. Alexandrie, 6. Nasr'Allah, 7. Seychelles.

Caractères : 1. Poids, 2. Nombre de soies abdominales, 3. Nombre de soies sternopleurales, 4. Longueur du thorax, 5. Longueur de l'aile, 6. Nombre d'ovarioles.

Examination of these data shows that they are not distributed at random. A regular pattern can be observed, allowing the calculation of the average values given in table 5 .

Distances between populations of the same geographic origin are always low $(\overline{\mathrm{m}}=2.4)$ while distances between European and Afrotropical flies are high $(\overline{\mathrm{m}}=25.2)$. North African populations occupy an intermediate position between these two groups from which they are equidistant (11.5 and 11.4). If we now consider the Seychellian population (table 4) we see that it is very close to north African flies and most distant from the French ones. 
TABLE 4

Correlations (above diagonal) and empirical distances (below diagonal) between the 7 biometrical profiles shown in figure 1

(see text for details).

Corrélations (au-dessus de la diagonale) et distances empiriques (au-dessous de la diagonale) entre les 7 profils biométriques de la figure 1

(voir le texte pour plus de détails).

\begin{tabular}{|c|c|c|c|c|c|c|c|c|}
\hline \multicolumn{9}{|c|}{ CORRELATIONS } \\
\hline \multirow{8}{*}{ 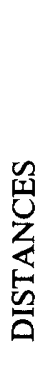 } & & Mal. & Vill. & Braz. & Cot. & Alex. & Nas. & Sey. \\
\hline & Mal. & & .592 & .981 & .386 & -.705 & -.703 & -.949 \\
\hline & Vill. & 1.13 & & 691 & .791 & -.987 & -.854 & -.562 \\
\hline & Braz. & 14.35 & 13.24 & & .504 & -.796 & -.753 & -.972 \\
\hline & Cot. & 37.02 & 36.36 & 5.69 & & -.779 & -.885 & -.381 \\
\hline & Alex. & 11.28 & 10.23 & 5.74 & 16.18 & & .874 & .687 \\
\hline & Nas. & 13.03 & 11.62 & 6.63 & 17.13 & 0.55 & & .600 \\
\hline & Sey. & 19.54 & 16.07 & 5.09 & 9.11 & 2.29 & 2.70 & \\
\hline
\end{tabular}

Correlation coefficients are highly variable, ranging from -0.987 to 0.981 . However, a regular pattern is also observed (table 5 ). Between populations of the same origin, a positive correlation is observed $(r=0.66)$. North African populations, on the other hand, are negatively correlated both to European and Afrotropical ones. An unexpected result is the positive correlation between the most distant populations from Europe and tropical Africa. For the moment, it seems premature to suggest an explanation to these observations and also to the fact that no $r$ values are close to zero (table 4).

\section{TABLE 5}

Comparison of biometrical profiles between different groups of populations ( $n$ : number of values)

Comparaison des profils biométriques entre différents groupes de populations ( $n$ : nombre de valeurs)

\begin{tabular}{c|c|c|c}
\hline \hline Populations compared & $\mathrm{n}$ & \multicolumn{1}{|c}{ Distance } & \multicolumn{1}{c}{ Correlation } \\
\hline Same geographic area .............. & 3 & $2.46 \pm 1.62$ & $0.656 \pm 0.11$ \\
Europe - Tropical Africa ........... & 4 & $25.24 \pm 6.61$ & $0.712 \pm 0.12$ \\
Europe - North Africa ........... & 4 & $11.54 \pm 0.58$ & $-0.812 \pm 0.07$ \\
North Africa - Tropical Africa ...... & 4 & $11.42 \pm 3.03$ & $-0.803 \pm 0.03$ \\
\hline
\end{tabular}




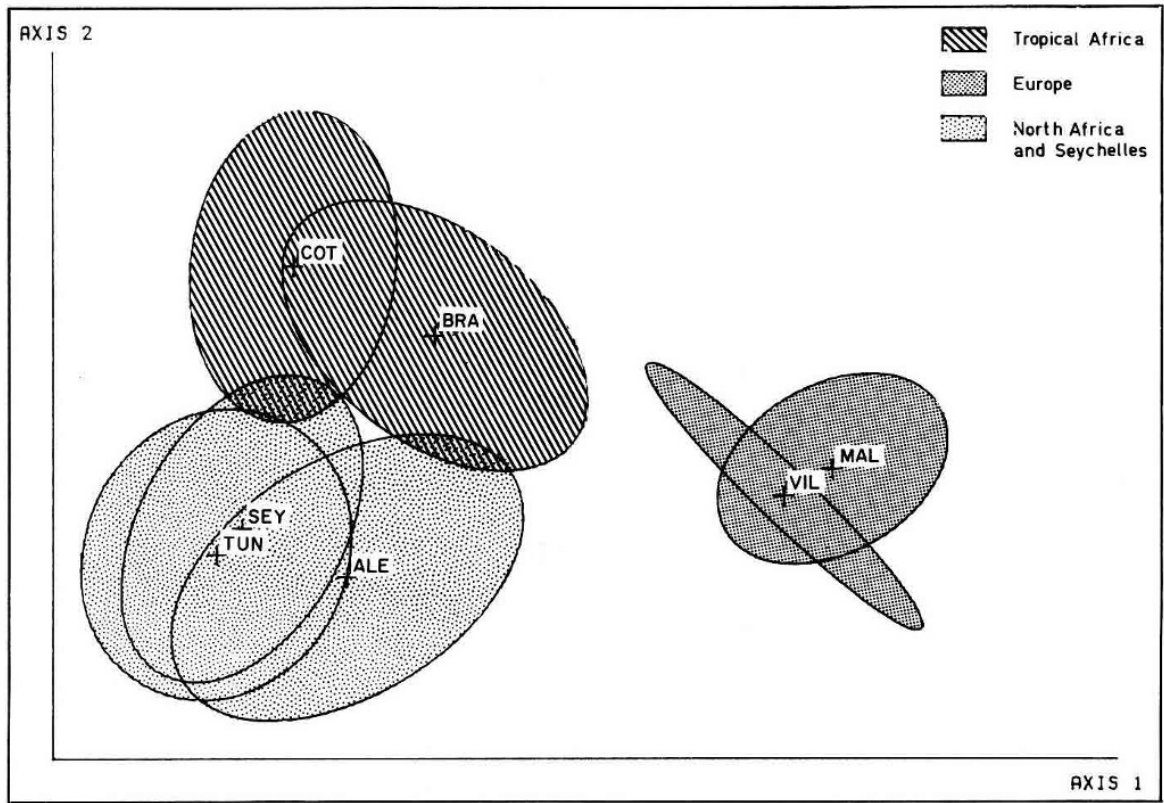

FIG. 2

Discriminant analysis applied to biometrical traits of the seven populations : projection on the first two discriminant axes of French, Afrotropical, north African and Seychellian populations. Each ellipse is calculated for including $75 \%$ of all observations. The two first axes restitute $97.4 \%$ of the total information.

Analyse discriminante appliquée aux caractères biométriques des sept populations : projection sur les deux premiers axes des populations françaises, d'Afrique tropicale, d'Afrique du Nord et des Seychelles. Chaque ellipse contient $75 \%$ des observations d'une population. Les deux premiers axes restituent $97,4 \%$ de l'information totale.

Looking at Seychellian flies, we again find that they are very close to the north African populations. Both for the distance and the correlations between biometrical profiles, Seychellian flies could be incorporated to the north African group without any significant modification of the average values given in table 5 .

Another way of comparing the 7 populations is to use a discriminant analysis. The results shown in figure 2 lead to a similar conclusion : the populations are distributed into three groups. The first axis, for which the main variables are thorax and wing lengths and ovarioles number, separates European populations from the others. The second axis with weight and abdominal chaetea number as preponderant variables, discriminates Afrotropical and north African populations. Seychellian flies are superimposed to this last group.

\section{Ethanol tolerance}

Survival curves of adults after two days of treatment with various concentrations of ethanol are given in figure 3. These curves show the high sensitivity of Afrotropical flies (lethal concentration $50=6.5 \%$ ) and the high tolerance of European and Seychellian flies (L.C. 50 of 17.0 and $16.7 \%$ respectively) as already described (DAVID and CAPY, 1982). 


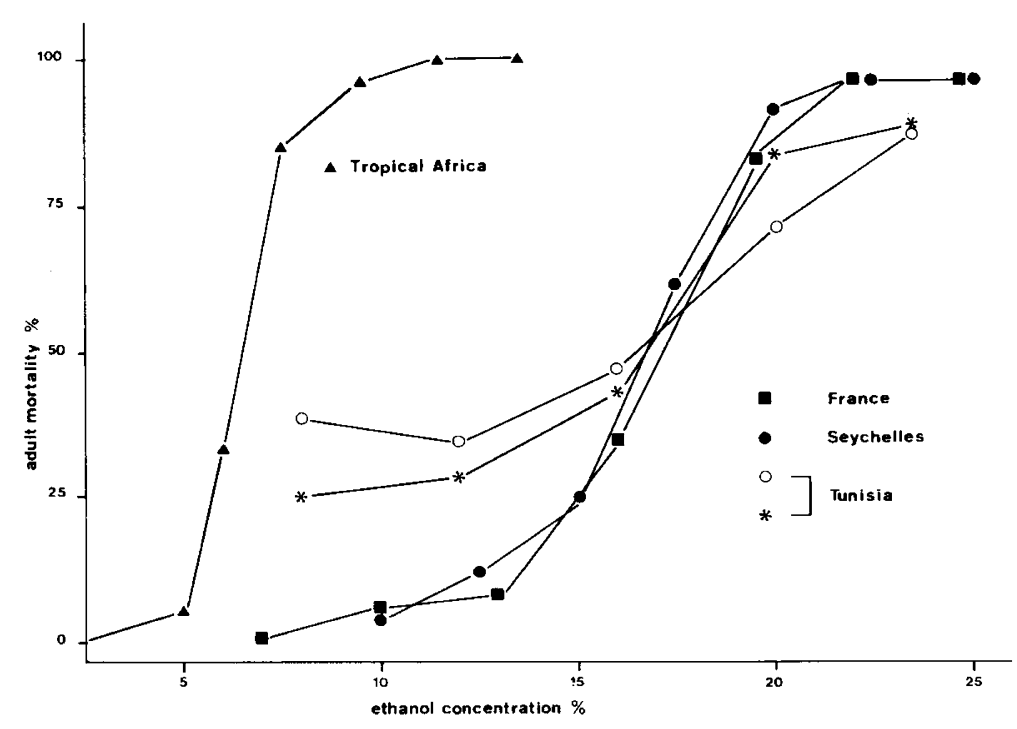

FIG, 3

Comparison of the ethanol tolerance of Tunisian flies (two repeats) with that of Afrotropical, European and Seychellian flies.

The curves show the percent of adult mortality after two days of treatment on various concentration of ethanol. The lethal concentration 50 are respectively $6.5 \%$ (tropical Africal), $17 \%$ (Europe), $16.7 \%$ (Seychelles) and $16.6 \%$ and $16.7 \%$ (Tunisia).

Comparaison de la tolérance à l'éthanol de mouches tunisiennes (2 répétitions) avec celles des populations d'Afrique équatoriale, européennes et des Seychelles.

Les courbes donnent le pourcentage de mortalité adulte après deux jours de traitement pour diverses concentrations d'éthanol. Les doses létales 50 sont respectivement 6,5\% (Afrique tropicale), $17 \%$ (Europe), 16,7 \% (Seychelles) et 16,6\% et 16,7\% (Tunisie).

Two measurements were done on mixed strains of Tunisian flies. For the L.C. 50, the values were found to be almost identical to those of European flies (16.6 and 16.7 \%). However, the mortality curves exhibit a smoother slope, suggesting a greater variability between individuals. More specially we see that about $30 \%$ of the flies were killed by a relatively low concentration of $8 \%$ ethanol. This observation was confirmed in two other repeats (not shown). The occurrence of a great variability of ethanol tolerance between sympatric flies seems a specific property of the Tunisian population.

\section{Daily oviposition rhythm}

The average oviposition curves, under a LD 12.12 regime, are given in figure 4.

In all cases, we observe an oviposition peak at the beginning of the scotophase which is typical of $D$. melanogaster. The data also confirm that the height of the peak is much more important in Afrotropical than in European populations (AllEMAND and DAVID, 
1976). The Tunisian population exhibits a peak which is a little higher than in French populations, as could be expected from the latitudinal cline previously described (ALLEMAND and DAviD, 1976). The Seychellian population, despite its position close to the Equator, is almost identical to the French one.
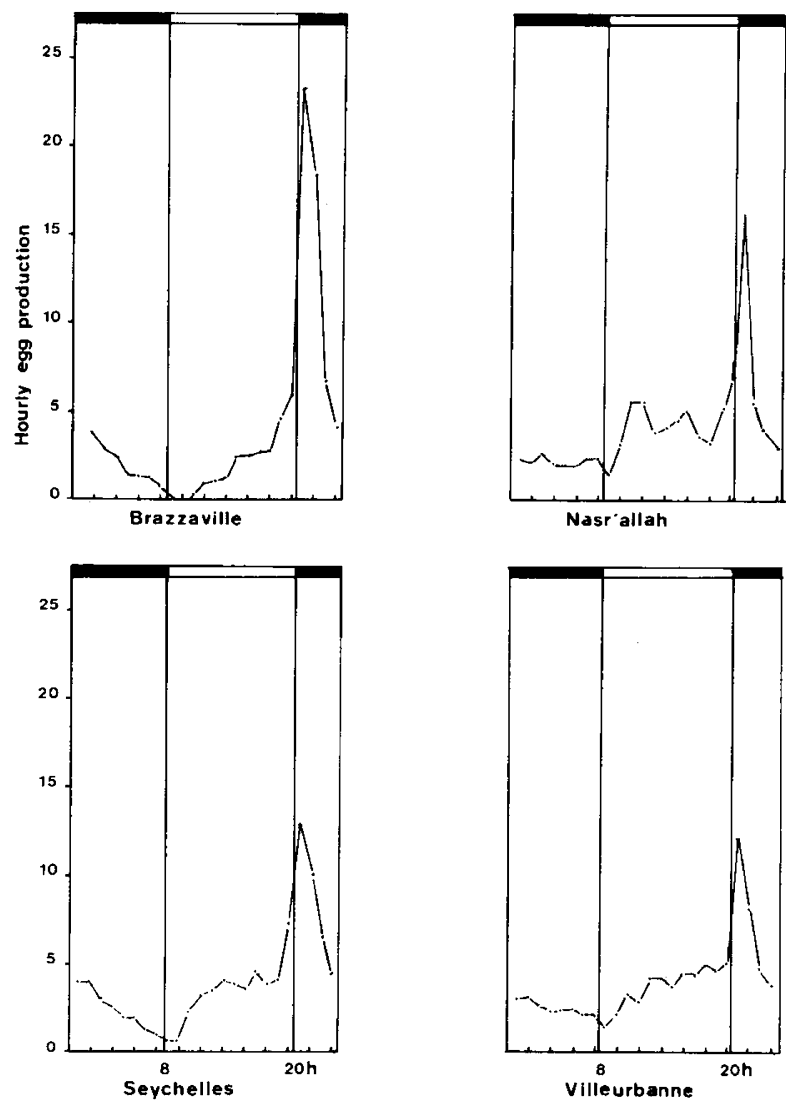

FIG. 4

Daily oviposition curves of flies from tropical Africa (Brazzaville), Tunisia (Nasr'Allah), France (Villeurbanne) and Seychelles.

Heavy and light bars indicate the photoperiodic cycle. Hourly data are expressed in percent of the daily egg production. Each curve is the average of several repetitions (between 14 and 20) and corresponds to a total oviposition of more than 3000 eggs.

Courbes de ponte journalière des mouches d'Afrique tropicale (Brazzaville), de Tunisie (Nasr'Allah), de France (Villeurbanne) et des Seychelles.

Les barres noires et blanches figurent le cycle photopériodique. Les données horaires sont exprimées en pourcentage de la production journalière. Chaque courbe est la moyenne de plusieurs répétitions (entre 14 et 20) et correspond à un total de plus de 3000 oufs. 


\section{Discussion and conclusion}

All genetic studies of natural populations of Drosophila are subject to a possible bias due to drift or selection when the offspring of wild living individuals are kept for several generations in the laboratory. For some traits, such as allozyme frequencies, this inconvenience can be avoided by directly studying wild collected flies or by keeping them, or their F1 offspring, deep frozen until the analysis is done. For other traits, for example morphological or physiological ones, the analysis must be done on flies grown under the controlled conditions of the laboratory in order to reduce the undesirable variation attributable to environmental effects (DAVID, 1979). Such traits are subject in the laboratory to genetic drift but it is also possible that some kind of selection will occur as a consequence of environmental stability or crowding. Studying isofemale lines appears a convenient technique for getting more accurate data on the genetic structure of natural populations (see PARSONS, 1980 , for a review). However, in many published cases, the lines were kept in the laboratory for more than $\mathbf{1 0}$ generations before the analysis so that we do not know if the experimental data exactly reflected the genetic properties of the original population. In the present work, we tried to avoid this problem by studying the second generation of laboratory grown flies. The fact that a cross between unrelated parents was done before the morphological analysis of the progeny also ensured that all individuals in a family were non-inbred, full sibs. We believe that this procedure is the best possible to get an instant picture of the genetic properties of a natural population. The only possible bias may arise from the fact that, when wild living females are isolated in single vials, some of them remain sterile or die prematurely. The possibility of some kind of laboratory adaptation cannot thus be completely excluded, but its importance seems minimal.

Two main problems are to be discussed from the presented data. First, what is the position of north African populations with respect to latitudinal clines ? Second, what may be the origin of the Seychellian population?

When plotted against latitude of origin, the points corresponding to different populations living approximatively at the same longitude are often organized according to a clinal pattern. As pointed out in the introduction, this has been demonstrated for morphological traits, ethanol tolerance, the peak of oviposition rhythm and for allozyme frequencies. However the corresponding points generally show a large dispersion around the regression line so that the question generally arises as to whether the scattering is due mainly to random events, such as sampling errors or laboratory drift, or if they correspond to true and permanent divergences between the populations ?

The answer to that question can be given only if each population is analyzed using an appropriate sampling technique such as isofemale lines, and also if the same population is studied over successive years. It is therefore not possible to suggest a definitive answer but our observations clearly favour the second hypothesis, as North African populations are often quite different from the general latitudinal tendency observed between Western Europe and Equatorial Africa. This conclusion is apparent from allozyme frequencies since, in spite of the lower latitude $\left(35^{\circ}\right.$ versus $\left.45^{\circ}\right)$ the Tunisian population is almost identical to European ones. This is also clear for the ethanol tolerance, the mean of which is similar to that observed in France. But the main evidence comes from the biometrical traits.

The two north African samples, in spite of their distant origins (more than $2000 \mathrm{~km}$ between Nasr'allah and Alexandria), show similar properties. For example the female ovariole number is almost identical to that found in Equatorial Africa while the number of abdominal chaetae is superior both to those of Afrotropical and European flies. 
Very little doubt remains that, superimposed to a general latitudinal tendency, local populations exhibit original genetic properties and deviate significantly from a linear cline.

Of course the same difficulty of interpretation still persists, as in all ecological genetics studies : are such short range divergences a consequence of drift or a consequence of adaptation to specific local environmental conditions ? Much more information is needed before we can give an accurate answer to that question which is crucial to population biology.

The special status of the Seychellian population may help to investigate further that problem. As discussed in an earlier paper (DAVID and CAPY, 1982) this population was probably introduced into the archipelago during the last 4 years. This population is very different from those living on the African mainland in a similar equatorial climate and close to those living in temperate countries. We demonstrate here that this population is, for its biometrical properties, closer to north African populations than to European ones, while the data for the other characteristics are not discriminative.

It could be tempting to argue that this population was introduced from North Africa. However a recent study (ANXOLABEHERE et al., 1982) of these populations for their genetic status in the P.M. system of hybrid dysgenesis demonstrated that north African populations were of the $M$ type while Seychellian and French populations were of the $Q$ type. Other origins should also be considered, specially countries for which we do not have any information on the genetic properties of wild living D. melanogaster. For example, South Africa is likely to harbour populations quite similar to those of North Africa. Finally the possibility remains that the biometrical similarity with north African flies is only a transient phenomenon of a temperate population submitted to new selective pressures and evolving toward a new genetic equilibrium.

Received October 22, 1982. Accepted January 21, 1983.

\section{Acknowledgements}

We thank Mrs De Scheemaeker-Louis, E. Pla and J. Sandrin for excellent assistance in this study and Dr. F. Borai for providing the Alexandria population.

\section{References}

Allemand R., 1974. Importance évolutive du comportement de ponte chez les insectes : comparaison du rythme circadien d'oviposition chez les six espèces de Drosophila du sous-genre melanogaster. C.R. Acad. Sci., Paris, 279, 2075-2077.

Allemand R., David J.R., 1976. The circadian rhythm of oviposition in Drosophila melanogaster : A genetic latitudinal cline in wild populations. Experientia, 32, 1403-1404.

Anxolabehere D., Nouaud D., Periquet G., 1982. Etude de la variabilité du système P.M. de dysgénésie des hybrides entre populations de Drosophila melanogaster. C.F. Acad. Sci., Paris, 294, 913-916.

Ayala F.J., Tracey M.L., Barr L.G., McDonald J.F., Perez-Salas S., 1974. Genetic variation in natural populations of five Drosophila species and the hypothesis of the selective neutrality of protein polymorphisms. Genetics, 77, 343-384.

CAPY P., 1982. Variabilité génétique et races géographiques chez Drosophila melanogaster : Etude de caractères biométriques par la méthode des lignées isofemelles. Thèse de $3^{\mathrm{e}}$ Cycle. Orsay (Paris XI). 
DAviD J.R., 1979. Utilization of morphological traits for the analysis of genetic variability in wild populations. Aquilo, (Ser. Zool.), 20, 49-61.

DAvid J.R., 1982. Latitudinal variability of Drosophila melanogaster : Allozyme frequencies divergence between European and Afrotropical populations. Biochem. Genet., 20, 7/8, 747-761.

DAvid J.R., BocQuET C., 1975a. Evolution in a cosmopolitan species : Genetic latitudinal clines in Drosophila melanogaster wild populations. Experientia, 31, 164-166.

DAVID J.R., BocQuET C., 1975b. Similarities and differences in latitudinal adaptation of two Drosophila sibling species. Nature, 257, 588-590.

David J.R., Bocquet C., De Schemaeker-Louis M., 1977. Genetic latitudinal adaptation of Drosophila melanogaster : New discriminative biometrical traits between European and Equatorial African populations. Genet. Res. Camb., 30, 247-255.

DAVID J.R., CAPY P., 1982. Genetics and origins of a Drosophila melanogaster population recently introduced to the Seychelles. Genet. Res., Cambridge, (in press).

David J.R., Fouillet P., Arens M.F., 1974. Comparaison de la sensibilité à l'alcool éthylique de six espèces de Drosophila du sous-groupe melanogaster. Arch. Zool. exp. gén., 115, 401-410.

David J.R., Tsacas L., 1981. Cosmopolitan, subcosmopolitan and widespread species : Different strategies within the Drosophilid family (Diptera). C.R. Soc. Biogeog., 57, 11-13.

Dobzhansky T., 1970. Genetics of the evolutionary process. Colombia Univ. Press, New York. $505 \mathrm{p}$.

Endler J.A., 1977. Geographic variation, Speciation and Clines. Princeton Univ. Press.

Kimura M., 1979. The neutral theory of molecular evolution. Sci. Amer., 241, 98.

KimURA M., MaruYama T., 1971. Pattern of neutral polymorphism in a geographically structured population. Genet. Res., 18, 125-131.

LEFEBVRE J., 1978. Introduction aux analyses statistiques multidimensionnelles. Masson, Paris.

LEWONTIN R.C., 1974. The genetic basis of evolutionary change. Columbia Univ. Press, New York.

Louis J., Rouault J., David J., CAPY P., 1982. Altitudinal variations of Afrotropical D. melanogaster populations. Drosophila Inform. Serv. (sous presse).

MAYr E. 1963. Animal species and Evolution. Belknap press, Cambridge (U.S.A.).

MetTleR I.E., Voelker R.A., MUKAI T., 1977. Inversion clines in populations of Drosophila melanogaster. Genetics, 87, 169-176.

MilKMAN R., ZeitleR R., 1974. Concurrent multiple paternity in natural and laboratory populations of Drosophila melanogaster. Genetics, 78, 1191-1193.

NEI M., 1972. Genetic distance between populations. Am. Nat., 106, 283-290.

Nevo E., 1978. Genetic variation in natural populations : patterns and theory. Theoret. Popul. Biol., 13, $121-177$.

OAKeshotT J.G., Chambers G.K., Gibson J.B., Willcoks D.A., 1981a. Latitudinal relationship of Esterase-6 and phosphoglucomutase gene frequencies in Drosophila melanogaster. Heredity, 47 (3) : 385-396.

OAKeshott J.G., Gibson J.B., Anderson P.R., KnibB W.R., Anderson D.G., Parsons P.A., 1980. Isofemale strains and evolutionary strategies in natural populations. Evolut. Biol., 13, 175-217.

Powell J.R., 1975. Protein variation in natural populations of animals. Evolut. Biol., 8, 79.

ChAMBERS G.K., 1981b. Alcohol dehydrogenase and glycerol-3-phosphate dehydrogenase clines in Drosophila melanogaster on different continents. Evolution, 36 (1), 86-96.

SINGH R.S., HICKEY D.A., DAVID J.R., 1982. Genetic differentiation between geographically distant populations of Drosophila melanogaster. Genetics, (in press).

TaNTAwy A.O., Mallah G.S., 1961. Studies on natural populations of Drosophila. 1. Heat resistance and geographic Variation Drosophila melanogaster and D. simulans. Evolution, 15, 1-14.

Voelker R.A., Cockerham C.C., Johnson F.M., Schaffer H.E., Mukal T., MetTler L.E., 1978. Inversions fail to account for allozymes clines. Genetics, 88, 515-527. 